10IKC-207

\title{
METASOMATISM OF A ROBERTS VICTOR ECLOGITE LINKED TO THE FORMATION AND DESTRUCTION OF DIAMOND
}

\author{
RICHES ${ }^{1}$, A.J.V., PEARSON ${ }^{1}$, D.G., STERN ${ }^{1}$, R.A., ICKERT ${ }^{1}$, R.B., JACKSON ${ }^{3}$, S.E., ISHIKAWA ${ }^{2}$, A., \\ and KJARSGAARD ${ }^{3}$, B.A.,
}

\author{
${ }^{I}$ Dept. of Earth and Atmospheric Sciences, University of Alberta, Edmonton, Canada. \\ ${ }^{2}$ Dept. of Earth Science and Astronomy, The University of Tokyo at Komaba, Tokyo, Japan. \\ ${ }^{3}$ Geological Survey of Canada, Ottawa, Canada. \\ *Corresponding author ariches@ualberta.ca
}

\section{INTRODUCTION}

Eclogites ( \pm pyroxenite) may host significant quantities of diamonds in some portions of sub-continental lithospheric mantle (e.g., Orapa, Magondi Mobile Belt; Shee and Gurney, 1979; Argyle, Halls Creek Mobile Zone; Jaques et al., 1989; Nyurbinskaya, Siberian Craton; Spetsius et al., 2008; Riches et al., 2010). Although garnet concentrate data ( $n=534$ grains) suggest that significant proportions of peridotite are present in the sub-continental lithospheric mantle beneath the Roberts Victor kimberlite (85-97\% peridotite; Schulze et al., 1989), it is well established that the xenolith population of Roberts Victor is eclogite-rich, as eclogites account for $>95 \%$ of the xenoliths from this pipe (MacGregor and Carter, 1970; Hatton, 1978). Eclogites are broadly basaltic rocks that are widely considered to represent subducted crustal materials derived from oceanic lithosphere (e.g., Snyder et al., 1997; Jacob, 2004; Pearson et al., 2003; Taylor et al., 2003a; Riches et al., 2010). However, some Group-I eclogite xenoliths have textural features (including banding and zonation of modal abundances) that may not be explained by garnet formation during high-pressure transformation alone (e.g., Hatton and Gurney, 1987; Ishikawa et al., 2008a-b; Gréau et al., 2011).

Oxygen isotope compositions of eclogitic and pyroxenitic garnets have often been interpreted as a robust tracer of protolith materials (e.g., Snyder et al., 1997; Jacob et al., 2004, 2005), and, by analogy with shallow-level ophiolite and MORB sequences altered at low-temperatures (e.g., Gregory and Taylor, 1981; Alt et al., 1986), garnet $\delta^{18} \mathrm{O}-$ values significantly above $5.9 \%$ are frequently cited as evidence supporting a shallow origin for eclogites (e.g., Jagoutz et al., 1984; Snyder et al., 1997; Jacob et al., 2004; Spetsius et al., 2008; Riches et al., 2011). However, recent studies have questioned the robust nature of garnet $\delta^{18} \mathrm{O}$ values (Gréau et al., 2011); these authors reported oxygen isotope data for multiple garnet grains of Group-I and Group-II eclogites from Roberts Victor, and suggested that garnet $\delta^{18} \mathrm{O}$-values are correlated with incompatibleelement abundances.
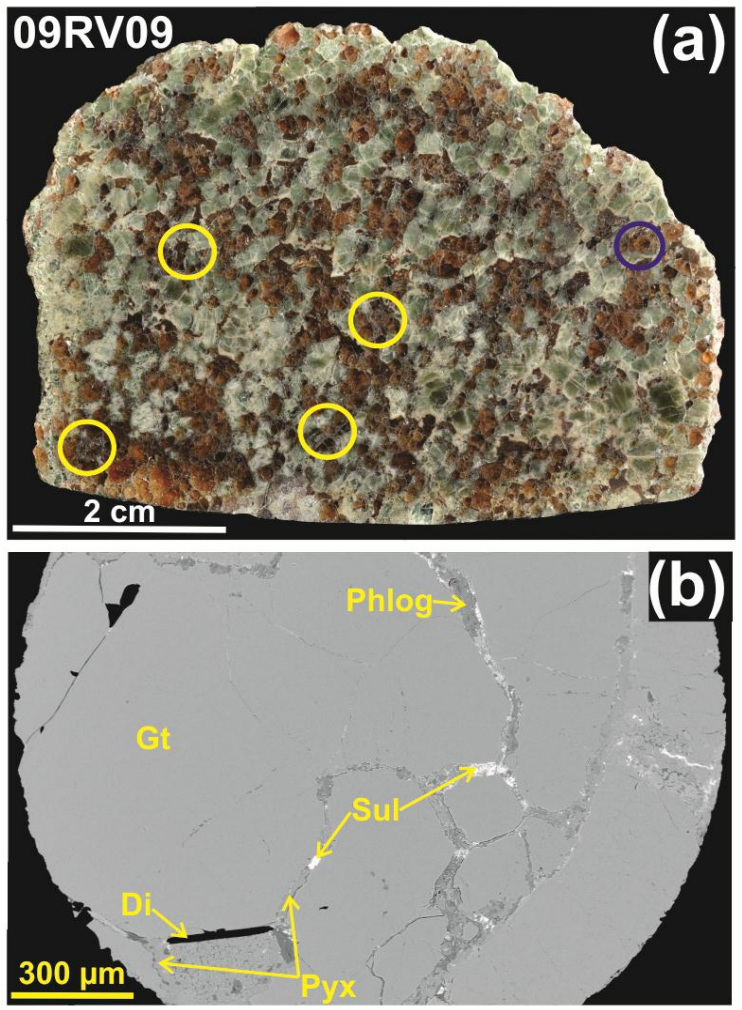

Figure 1: Photographic image of a large polished slice (a), and BSE image of a diamond-bearing portion (b) of a phlogopite-bearing Gt-websterite (09RV09) from the Roberts Victor kimberlite. In (a), circles outline subregions selected for in situ study, and the blue circle marks the diamond bearing portion shown in (b). Di $=$ diamond, $\mathrm{Gt}=$ garnet, $\mathrm{Phlog}=$ phlogopite, Pyx $=$ pyroxene, Sul $=$ sulphide.

We provide the first in situ measurements of $\delta^{18} \mathrm{O}$ compositions (determined by ion-microprobe) in garnet adjacent to diamond, and these data are supplemented by in situ major- and trace-element abundance data of garnets and coexisting phases. Our results show that; 1) $\delta^{18} \mathrm{O}$-values do not display measurable inter- and intra-grain oxygenisotope variation in Gt-rich and Cpx-rich portions $( \pm$ diamond \pm phlogopite) of 09RV09, and 2) garnet $\delta^{18} \mathrm{O}-$ 
values do not correlate with major- and trace-element abundances and inter-element ratios.

\section{RESULTS}

\subsection{Petrography and Mineralogy}

A diamond- and phlogopite-bearing Gt-websterite xenolith, 09RV09, of Roberts Victor, Kaapvaal Craton, contains regions with variable proportions of garnet and clinopyroxene (Fig. 1a). Garnet (up to $1.5 \mathrm{~mm}$ in maximum dimension) and clinopyroxene crystals (up to $2 \mathrm{~mm}$ in maximum dimension) dominate the matrix of this sample (>90 vol. \%), and lesser amounts of phlogopite (up to $1 \mathrm{~mm}$ in maximum dimension), sulphide (generally $<0.5 \mathrm{~mm}$ ), clino- and orthopyroxene ( $<0.5 \mathrm{~mm}$ maximum dimension), and diamond (up to $800 \mu \mathrm{m}$ in maximum dimension in the studied sections) generally occur as interstitial phases. Polycrystalline diamond-aggregates (up to $2 \mathrm{~mm}$ in maximum dimension) are located in other portions of 09RV09, and are not the focus of this work. In contrast to all Siberian diamondiferous-eclogites studied to date that do not contain diamond in contact with garnet (Taylor and Anand, 2004; Spetsius and Taylor, 2008), a $280 \mu \mathrm{m}$ elongate diamond (Fig. 1b) in 09RV09 is in direct contact with garnet along $200 \mu \mathrm{m}$ of its length. Calciumproportions $\left(\mathrm{Ca} \#=100 \mathrm{Ca} /\left[\mathrm{Ca}+\mathrm{Mg}+\mathrm{Fe}^{\text {total }}\right]\right)$ and $\mathrm{Mg \#}$ (where $\left.\mathrm{Mg} \#=100 \mathrm{Mg} /\left[\mathrm{Mg}+\mathrm{Fe}^{\text {total }}\right]\right)$ of all studied 09RV09 garnets define an antithetic correlation over a moderate range of Ca\# (9.01 to 10.7) and $\mathrm{Mg \#} \mathrm{(76.7} \mathrm{to} \mathrm{80.0).} \mathrm{Garnets}$ associated with phlogopite have $\mathrm{Mg \#}>77.5$ whereas garnets in phlogopite-free zones have $\mathrm{Mg} \#<77.5$, and all garnets record modest intra-grain variations in Ca\# $( \pm 0.4$ to 1.0 units) with no systematic core to rim trend.

\subsection{Trace-Element Compositions}

Garnets of 09RV09 are very consistent in their trace element compositions. They are exclusively LREE-depleted $\left([\mathrm{La} / \mathrm{Yb}]_{\mathrm{N}}=0.002\right.$ to 0.007$)$ with HREE-abundances of $\sim 9.5$ to $13 * \mathrm{CI}$-chondrite (Fig. $2 \mathrm{a}$ ), and $[\mathrm{Eu} / \mathrm{Eu} *]_{\mathrm{N}}$ values of 0.99 to 1.30 . Sinusoidal REE-patterns were not observed in garnet grains, including those in close association with diamond. High field strength element contents of 09RV09 garnets are broadly similar to those of some rutile-free eclogites (e.g., Jacob and Foley, 1999), with $[\mathrm{Zr} / \mathrm{Hf}]_{\mathrm{PM}}$ values ranging from 1.4 to 4.0.

\subsection{In situ Oxygen Isotope Data}

Oxygen isotope compositions of garnets in 09RV09 are all above 'typical' mantle values, ranging from $6.2 \%$ to $6.8 \%$ o (Fig. 2b), and analytical uncertainties are generally 0.3 to $0.4 \% 22 \sigma_{\text {stdev }}$ (combined internal and external precisions). The mean, mode, and median values of these data (a total of 94 points on 8 garnets from a range of textural locations) are within uncertainty of one another $(6.5 \%, 6.6 \%$, $6.5 \%$, respectively), and no detectable inter- and intra-grain $\delta^{18} \mathrm{O}$ variations are recorded in garnets of this xenoliths.
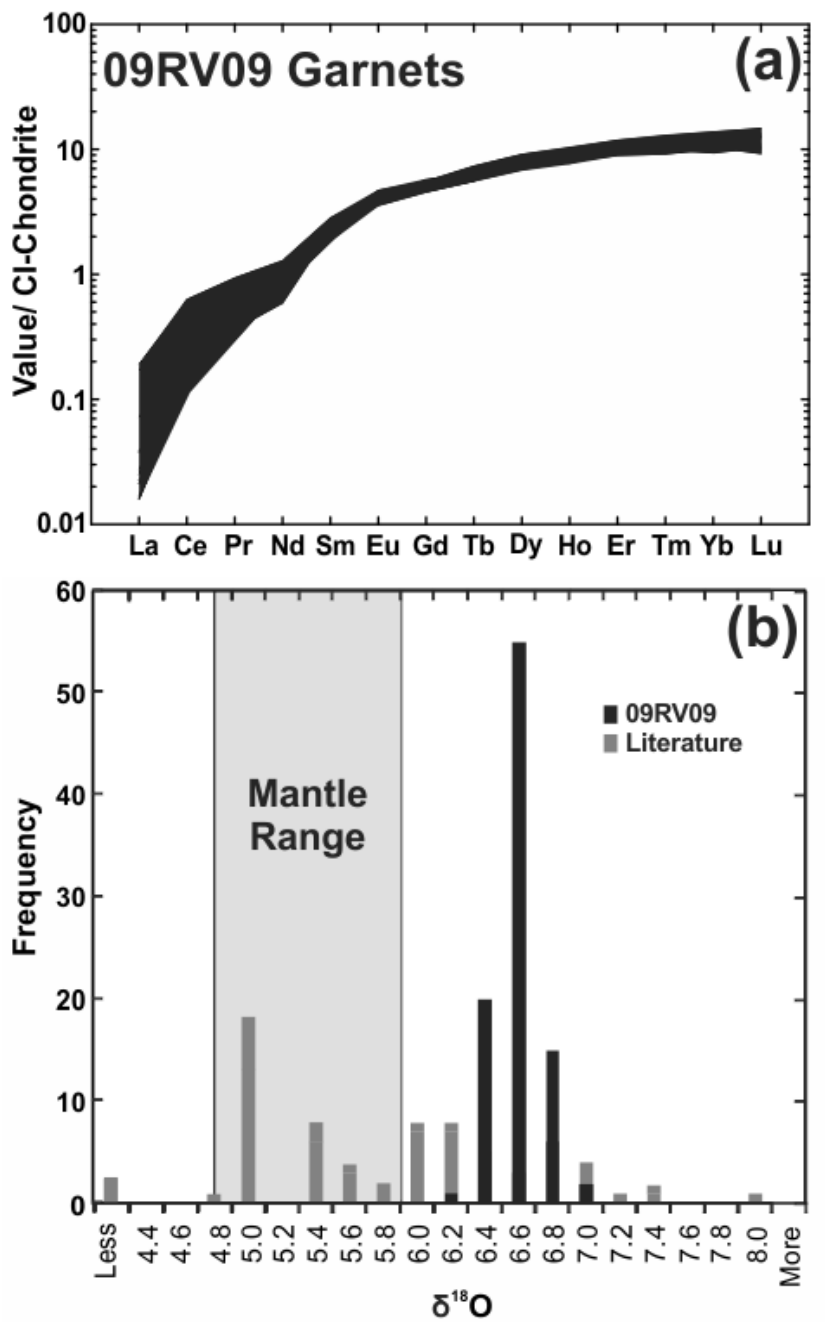

Figure 2: Rare-earth-element (REE) contents of 09RV09 garnets determined by LA-ICP-MS (a) normalized the CI-chondrite value of McDonough and Sun (1995), and (b) oxygen isotope compositions of garnets determined in this study of a single xenolith compared to those determined for garnets of numerous xenoliths in previous publications (Garlick et al., 1971; Ongley et al., 1987; Caporuscio, 1990; Schulze et al., 2000; Gréau et al., 2011) and the range defined for 'typical' mantle garnets (Valley et al., 1998).

\section{SUMMARY}

Previous studies of Group-I eclogites (including Gtwebsterites) have noted striking modal variations that may be related to metasomatic processes (e.g., Hatton and Gurney, 1987; Ishikawa et al., 2008a-b; Gréau et al., 2011). Our in situ investigation of a single diamondiferous Roberts Victor Gt-websterite with garnet $\delta^{18} \mathrm{O}$-values above the mantle-range shows no correlation between major- and trace-element abundances and oxygen isotope compositions. This information suggests that metasomatism by small-volume fluids and/or melts potentially linked to the formation and/or destruction of diamonds (e.g., Deines et al., 1987; Taylor et al., 1996,1998,2003b; Ishikawa et al., 2008a-b; Izraeli et al., 2001; Navon et al., 2003; Klein- 


\section{$10^{\text {th }}$ International Kimberlite Conference, Bangalore - 2012}

BenDavid et al., 2006, 2010; Tomlinson et al., 2006; Rege et al., 2008; Liu et al., 2009) has not created secondary $\delta^{18} \mathrm{O}$-signatures. These results are consistent with previous eclogite studies (e.g., Snyder et al., 1997; Jacob, 2004,2005; Spetsius et al., 2008; Riches et al., 2011), which indicated that garnet oxygen isotope compositions provide a robust trace of the source lithology. Given the ancient ages (2.7$3.5 \mathrm{Ga}$ ) determined for several Roberts Victor eclogite samples (e.g., Shirey et al., 1999a-b, 2001) this information is of great importance for understanding the origin and evolution of Archean sub-continental lithospheric mantle.

\section{AKNOWLEDGEMENTS}

We thank John Gurney for donating the Gt-websterite sample used in this study.

\section{REFERENCES}

Alt, J. C., Muehlenbachs, K., and Honorez, J., 1986. Earth Planet. Sci. Lett., 80, 217-229.

Caporuscio, F. A., 1990. Lithos, 25(1-3), 203-210.

Deines, P., Harris, J. W., and /Gurney, J. J., 1987. GCA, 51, 1227-1243.

Garlick, G. D., MacGregor, I. D., and Vogel, D. E., 1971. Science, 172, 1025-1027.

Gréau, Y., Huangm J.-X., Griffin, W. L., Renac, C., Alard, O., and O’Reilly, S. Y., 2011, GCA, 75, 6927-6954.

Gregory, R. T., and Taylor, Jr., H. P., 1981. J. Geophys. Res, 86, $2737-$ 2755.

Hatton, C. J., 1978. Ph.D thesis, Univ. Cape Town.

Hatton, C. J., and Gurney, J. J., 1987, In: Mantle Xenoliths.

Ishikawa, A., Pearson, D. G., Maruyama, S., Cartigny, P., Ketcham, R. A., and Gurney, J. J., 2008. $9^{\text {th }}$ IKC, abstract \#00078.

Ishikawa, A., Pearson, D. G., Maruyama, S., de Bruin, D., and Gurney, J J., 2008, $9^{\text {th }}$ IKC, abstract \#00079.

Izraeli, E. S., Harris J. W., and Navon O., 2001. Brine inclusions in diamonds: a new upper mantle fluid. Earth Planet. Sci. Lett., 187(3-4), 323-332.

Jacob, D. E., 2004. Lithos, 77, 295-316.

Jacob, D. E., and Foley, S. F., 1999. Lithos, 48, 317-336.

Jacob, D. E., Bizimis, M., Salters, V. J. M., 2005. Contrib. Mineral. Petrol., 148, 707-720.

Jagoutz, E., Dawson, J. B., Hoernes, S., Spettel, B., and Waenke, H., 1984. In: Lunar and Planet. Inst. Workshop on Early Earth., pp. 40-41.

Jaques, J. L., Hall, A. E., Sheraton, J. W., Smith, C. B., Sun, S.-s., Drew, R. M., Foudoulis, C., and Ellingsen, K., 1989, In Kimberlites and Related Rocks: Their Crust Mantle Setting.

Klein-BenDavid, O., Izraeli, E S., Hauri, E., and Navon, O., 2004. Mantle fluid evolution - a tale of one diamond. Lithos 77, 243-253.

Klein-BenDavid, O., Pearson, D. G., Nowell, G. M., Ottley, C., McNeill, J. C. R., and Cartigny, P., 2010. Mixed fluid sources involved in diamond growth constrained by $\mathrm{Sr}-\mathrm{Nd}-\mathrm{Pb}-\mathrm{C}-\mathrm{N}$ isotopes and trace elements. Earth Planet. Sci. Lett., 289, 123-133.

Liu, Y., Taylor, L. A., Sarbadhikari, A. B., Valley, J. W., Ushikubo, T., Spicuzza, M. J., Kita, N., Ketcham, R. A., Carlson, W., Shatsky, V., Sobolev, N. V., 2009. Lithos, 112, 1014-1024.

MacGregor, and Carter, 1970. Phys. Earth Planet. Interiors, 3, 391-397.

McDonough, W. F., and Sun, S.-s., 1995, Chem. Geol., 120, 223-253.

Navon, O., Izraeli, E. S., and Klein-BenDavid, O., 2003. Fluid inclusions in diamonds: the carbonatitic connection. $8^{\text {th }} \mathrm{IKC}$, abstract \#107.

Ongley, J. S., Basu, A. R., and Kyser, T. K., 1987. EPSL, 83(1-4), 80-84.

Pearson D. G., Canil, D., and Shirey, S. B., 2003. In: Treatise on Geochemistry.

Riches, A. J. V., Liu, Y., Day, J, M. D., Spetsius, Z. V., and Taylor, L. A., 2010. Lithos, 120, 368-378.

Schulze, D. J., 1989. J. Geophy. Res., 94, 4205-4212.
Schulze, D. J., Valley, J. W., and Spicuzza, M. J., 2000. Lithos, 54(1-2), 23-32.

Shee, S. R., and Gurney, J. J., 1979, In: The Mantle Sample: Inclusions in Kimberlites and Related Rocks.

Shirey, S. B., Wiechert, U., Carlson, R. W., Gurney, J. J., and Van Heerden, L., 1999a. $9^{\text {th }}$ Annual Goldschmidt Conf., abstract \# 7630.

Shirey, S. B., Carlson, R. W., Gurney, J. J., and Van Herden, J., 1999b. $7^{\text {th }}$ $\mathrm{IKC}$,

Shirey, S. B., Carlson, R. W., Richardson, S. H., Menzies, A., Gurney, J. J., Pearson, D. G., Harris, J. W., and Wiechert, U., 2001. Geophys. Res. Lett., 28, 2509-2512.

Snyder, G. A., Taylor, L. A., Crozaz, G., Halliday, A. N., Beard, B. L., Sobolev, V. N., and Sobolev, N. V., 1997. JPET, 38(1), 85-113.

Spetsius, Z. V., Taylor, L. A., Valley, J. W., Deangelis, M. T., Spicuzza, M., and Ivanov, A. D., 2008. Eur. J. Mineral., 20, 375-385.

Spetsius Z. V., and Taylor, L. A., 2008. Diamonds of Siberia, Photographic Evidence for their Origin.

Taylor, L. A., and Anand, M., 2004. Chemie der Erde, 64, 1-74.

Taylor, L. A., Snyder, G. A., Crozaz, G., Sobolev, V. N., Yefimova, E. S., Sobolev, N. V., 1996. Earth Planet. Sci. Lett., 142(3-4), 535-551.

Taylor, L. A., Milledge, J. H., Bulanova, G. P., Snyder, G. A., and Keller, R. A., 1998. Metasomatic Eclogitic Diamond Growth: Evidence from Multiple Diamond Inclusions. Int. Geol. Rev., 40(8), 663-676.

Taylor, L. A., Snyder, G. A., Keller, R., Remley, D. A., Anand, M., Wielsi, R., Valley, J. W., and Sobolev, N. V., 2003a. Contrib. Mineral. Petrol., $145,424-443$

Taylor, L. A., Anand, M., Promprated, P., Floss, C., and Sobolev, N. V., 2003b. The significance of mineral inclusions in large diamonds from Yakutia, Russia. Amer. Mineral., 88(5-6), 912-920.

Tomlinson, E. L., Jones, A. P., and Harris, J. W., 2006. Co-existing fluid and silicate inclusions in mantle diamond. Earth Planet. Sci. Lett., 250, 581-595.

Valley, J. W., Kinny, P. D., Schulze, D. J., and Spicuzza, M. J., 1998, CMP, 133, 1-13. 